\title{
Pengaruh Penerapan Model Pembelajaran Kooperatif Tipe CIRC (Cooperative Integrated Reading and Composition) terhadap Kemampuan Pemecahan Masalah Soal Matematika Siswa Kelas VIII SMP Negeri 2 Bengkalis
}

\author{
Muhammad Fahmi *
}

* SMP Negeri 2 Bengkalis

\section{INFO ARTIKEL}

\section{Riwayat Artikel:}

Diterima: 6 Maret 2018

Disetujui: 10 Juni 2018

\section{Kata kunci:}

Pembelajaran Kooperatif Cooperative Integrated Reading ang Composition

Pemecahan Masalah

Soal Matematika

\section{Alamat Korespondensi:}

Muhammad Fahmi,

SMP Negeri 2 Bengkalis

Jl. Kelapapati Tengah, DAMON, Kec. Bengkalis, Kab. Bengkalis

E-mail: muhammad.fahmi@gmail.com

\begin{abstract}
This research aim to to know there is or do not it him difference of ability of trouble-shooting between class using type cooperative model of CIRC (Cooperative Integreted Reading Composition and) at class student of VIII SMP Country 2 Bengkalis District Of Bengkalis Sub-Province of Bengkalis, and difference oflis make-up of ability of trouble-shooting. In research of its problem formula " Do there is difference between class using Model Co-Operative type of CIRC to ability of trouble-shooting of student mathematics in class of VIII SMP Country 2 Bengkalis? and Do there is difference of make-up of between class using type cooperative model of CIRC to ability of trouble-shooting of student mathematics?". This research represent research of experiment kuasi. Population in this research is class student of VIII SMP Country 2 Bengkalis amounting to 114 and people of sampel this research is class of VIII.B amounting to 23 people as experiment class and class of VIII.C amounting to 23 people as control class. Pursuant to result of analysis can be taken by conclusion that there are difference of ability of trouble-shooting of student mathematics between using type cooperative model of CIRC and conventional study. This seen from complete mean of result learn with type co-operative model of CIRC equal to 83,30 is better the than result learn with conventional study equal to 73,96 , and difference of improvement can be seen from test of tes $\mathrm{N}$-Gain $\mathrm{t}$ that is equal to 4,07 . There by can be concluded that there are influence which are positive when using type cooperative model of CIRC to ability of trouble-shooting of student of SMP Country 2 Bengkalis.
\end{abstract}

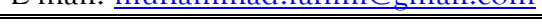

\section{LATAR BELAKANG}

Indikasi pemecahan masalah dalam pembelajaran matematika adalah agar siswa mampu memecahkan masalah yang dihadapi dalam kehidupannya, sehingga matematika merupakan salah salah satu ilmu yang penting untuk dipelajari baik dari tingkat dasar hingga perguruan tinggi. Dengan mempelajari matematika siswa selalu dihadapkan kepada masalah matematika yang terstruktur, sistematis dan logis yang dapat membiasakan siswa untuk mengatasi masalah yang timbul secara mandiri dalam kehidupannya tanpa harus selalu meminta bantuan kepada orang lain. Kemampuan pemecahan masalah matematika pada siswa dapat diketahui melalui soal-soal yang berbentuk uraian atau cerita, karena pada soal yang berbentuk uraian atau cerita kita dapat melihat langkahlangkah yang dilakukan siswa dalam menyelesaikan suatu permasalahan, sehingga pemahaman siswa dalam pemecahan masalah dapat terukur. Bentuk soal pemecahan masalah yang difokuskan pada penelitian ini adalah 
soal cerita, berdasarkan buku-buku penunjang pelajaran matematika yang mengacu pada kurikulum, banyak dijumpai soal-soal yang berbentuk soal cerita hampir pada setiap materi pokok. Menyelesaikan soal matematika bukan hanya untuk menerapkan matematika saja tetapi untuk belajar matematika yang baru, maksudnya saat siswa melibatkan diri dalam tugas-tugas berbasis soal yang dipilih dengan baik dan memfokuskan pada metodemetode penyelesaian, maka apa yang akan terjadi adalah pemahaman baru tentang matematika yang tersisipkan di dalam tugas tersebut.

Namun kenyataannya banyak siswa yang mengalami kesulitan belajar matematika. Kesulitan-kesulitan yang dihadapi siswa dalam belajar matematika, kesulitan dalam bahasa dan membaca juga berperan penting dalam mempelajari matematika. Seperti yang dinyatakan Lerner ada beberapa karakteristik anak berkesulitan belajar matematika, yaitu: adanya gangguan dalam hubungan keruangan, kesulitan mengenal dan memahami simbol, kesulitan dalam bahasa dan membaca (Abdurrahman, 2003). Soal matematika yang berbentuk cerita menuntut kemampuan bahasa dan membaca yang tinggi untuk memecahkan masalah matematika. Kenyataanya dari hasil observasi siswa kelas VIII SMP Negeri 2 Bengkalis memperlihatkan bahwa mereka kesulitan dalam memecahkan persoalan matematika yang diberikan khususnya dalam memecahkan masalah soal cerita, ini bisa dilihat mereka sulit dalam mengidentifikasi masalah, memahami makna dari soal, menemukan dengan tepat apa arti masalah, selain itu mereka juga sulit dalam merubah soal cerita yang ada kedalam model matematika. Hal ini salah satu penyebabnya dikarenakan siswa kurang pemahaman dalam membaca atau pemahaman linguistik serta menulis, yang berarti bahwa murid perlu memahami seluruh arti kalimat yang terdapat di dalam soal serta menulis dalam kalimat matematika. Walaupun membaca dan menulis pada matematika berbeda dengan membaca dan menulis secara umum namun ia sangat berperan penting dalam menyelesaikan permasalahan matematika. Kita ketahui membaca soal matematika tidak hanya membaca secara harfiah saja namun membutuhkan cara berpikir logis. Akan tetapi pada kenyataannya di sekolah, membaca hanya lebih menekankan pada kalimat harfiahnya saja tanpa memahami makna yang sebenarnya, menganalisis makna yang terkandung dalam kalimat yang dibaca tersebut. Seperti yang dinyatakan Guszak dalam penelitiannya pada tingkat sekolah dasar, Guszak menyatakan: "adanya penekanan yang berlebihan pada kemampuan memahami bacaan secara harfiah daripada kemampuan memahami bacaan secara secara interpretif dan logis" (E Slavin, 2005) dari pernyetaan Guszak ini dapat juga kita tangkap kurangnya kemampuan membaca inilah yang menyebakan kurangnya kemampuan siswa dalam memecahkan masalah matematika yang berbentuk soal cerita yang memerlukan analisis dalam membacanya.

Selain itu juga aktivitas siswa selama proses pembelajaran belum memuaskan karena pembelajaran masih didominasi oleh guru. Kegiatan pembelajaran yang demikian menunjukan bahwa pembelajaran berpusat pada guru, siswa tidak diarahkan untuk belajar mandiri dan bekerjasama. Sedangkan prinsip pembelajaran yang dituntut dalam Kurikulum Tingkat Satuan Pendidikan (KTSP) antara lain "pembelajaran berpusat kepada siswa, siswa diarahkan untuk belajar secara mandiri dan bekerjasama (Muslich, 2008).” Artinya, dalam proses pembelajaran yang aktif adalah siswa sedangkan guru hanya sebagai pembimbing dalam berlansungnya pembelajaran tadi.

Supaya tujuan pembelajaran dapat berjalan dengan efektif, maka setiap guru harus mengetahui berbagai metode yang dapat diterapkan dalam kegiatan pembelajaran sehingga pembelajaran bernilai edukatif. Nilai edukatif mewarnai interaksi yang terjadi antara guru dengan siswa. Interaksi yang bernilai edukatif dikarenakan kegiatan belajar mengajar yang dilakukan, diarahkan untuk mencapai tujuan tertentu yang telah dirumuskan sebelum proses pembelajaran dilakukan (Djamarah dan Zain, 2006). Proses pembelajaran yang dilakukan guru matematika SMP Negeri 2 Bengkalis yaitu mengajarkan atau menerangkan materi kemudian dilanjutkan dengan pemberian contoh soal, dan selanjutnya diakhiri dengan memberikan pekerjaan rumah atau PR. Guru juga mendorong siswa untuk bertanya jika ada materi yang belum mereka pahami. Pembelajaran tersebut kurang efektif karena pembelajaran tersebut masih bertumpu kepada guru sehingga siswa kurang aktif dan siswa cepat lupa terhadap pelajaran tersebut disebabkan siswa hanya menerima saja bukan menemukan dan memecah masalah matematika tersebut. Sehingga ada sebagian siswa yang memperoleh hasil belajar dibawah KKM, ini berarti menggambarkan kemampuan pemecahan masalah matematika siswa masih rendah.

Dari gejala-gejala yang telah dikemukakan, maka peneliti perlu mencari metode atau model yang tepat, agar tujuan dari pembelajaran itu tercapai. Menurut Suryadi dalam penelitiannya pada pelajaran matematika menyimpulkan bahwa "salah satu model pembelajaran yang efektif untuk meningkatkan kemampuan berpikir siswa adalah pembelajaran aktif (Isjoni, 2009).” Salah satu model pembelajaran yang efektif adalah pembelajaran kooperatif. Ada banyak model pembelajaran kooperatif dalam pembelajaran matematika yang memenuhi ciri pembelajaran efektif diantaranya model kooperatif tipe CIRC (Cooperative Integrated Reading and Composition). CIRC merupakan program komprehensif untuk mengajarkan membaca dan menulis pada tingkat yang lebih 
tinggi. Menurut Palinscar dan Brown "para siswa dalam CIRC juga membuat penjelasan terhadap prediksi mengenai bagaimana masalah-masalah akan diatasi dan merangkum unsur-unsur utama dari cerita kepada satu sama lain, yang ditemukan dapat meningkatkan pemahaman dalam membaca" (E. SLavin, 2005). Seperti yang diketahui dalam memecahkan masalah matematika memerlukan pemahaman membaca dan menulis yang tinggi apalagi berkaitan dengan bentuk soal cerita, sehingga dengan model pembelajaran CIRC siswa mampu dan terampil menyelesaikan masalah dalam soal cerita dengan langkah-langkah yang tepat.

\section{METODE}

Atikrel ini menggunakan penelitian kuasi eksperimen yang dilakukan di SMP Negeri 2 Bengkalis yang beralamat Jl. Kelapapati Tengah, Desa Damon, Bengkalis. Populasi dalam penelitian ini adalah seluruh siswa kelas VIII yang berjumlah 5 kelas semester ganjil SMP Negeri 2 Bengkalis, tahun ajaran 2012 sebanyak 114 peserta didik. Sampel diambil dari dua kelas yang ditentukan oleh peneliti yang sudah diuji tingkat homogenitas, normalitas, dan tingkat perbedaan kemampuan siswanya untuk lebih jelas bisa dilihat pada lampiran K. Di mana kelas VIII B sebagai kelas eksperimen yang akan digunakan strategi Pembelajaran dan kelas VIII C sebagai kelas kontrol dengan model pembelajaran konvensional. Teknik pengumpulan data ialah teknik atau cara-cara yang digunakan untuk mengumpulkan data. Metode atau Teknik menunjukkan suatu kata yang abstrak dan tidak diwujudkan dalam benda, tetapi hanya dapat dilihatkan penggunaannya melalui: angket, wawancara, pengamatan, ujian (tes), dokumentasi, dan lainnya. Peneliti dalam penelitian ini hanya menggunakan metode: pengamatan (lembar observasi), ujian (tes), dan dokumentasi. Teknik analisis data yang akan dilakukan pada penelitian ini adalah tes" $t$ " dan analisis deskriptif untuk lembar observasi. Tes " $t$ " adalah salah satu uji statistik yang digunakan untuk mengetahui ada atau tidaknya perbedaan yang signifikan (meyakinkan) dari dua buah mean sampel (dua buah variabel yang dikomparatifkan) (Hartono, 2008).

\section{HASIL DAN PEMBAHASAN}

\section{Kemampuan Pemecahan Masalah \\ Kemampuan Awal}

Berdasarkan hasil analisis data diperoleh informasi ternyata $\mathrm{F}_{\text {hitung }}<\mathrm{F}_{\text {tabel }}$ atau 1,2 $<2,03$, maka variansvarians adalah homogen. Sedangkan hasil uji normalitas, dapat diamati bahwa nilai $L_{\text {hitung }}$ kelas VIII B sebesar 0,1515 sedangkan untuk nilai $L_{\text {hitung }}$ kelas VIII C sebesar 0,1423. Harga $L_{\text {tabel }}$ dalam taraf signifikansi $5 \%$ untuk kelas VIII B adalah 0,1730 dan kelas VIII C 0.1730. Dengan demikian, $L_{\text {hitung }}<L_{\text {tabel }}$ maka dapat dikatakan bahwa data berasal dari populasi yang berdistribusi normal. Karena telah memenuhi kedua syarat tersebut, kemudian dilanjutkan analisis data dengan tes " $\mathrm{t}$ " dapat menggunakan uji statistik Compare Mare Independent Samples Test. Nilai thitung $=0,14$ berarti bahwa thitung lebih kecil tabel pada taraf signifikan 5\% maupun taraf signifikan $1 \%$ dengan $\mathrm{df}=\mathrm{N}_{\mathrm{x}}+\mathrm{N}_{\mathrm{y}}-2=23+23-2=44$. Dalam tabel tidak terdapat $\mathrm{df}=44$, maka dari itu digunakan df yang mendekati 44 yaitu $\mathrm{df}=45$. Dengan df diperoleh dari tabel pada taraf sidnifikan $5 \%$ dan $1 \%$ sebesar 2,02 dan 2,69. Ini berarti $t_{\text {hitung }}<t_{\text {tabel }}$, maka diputuskan bahwa $H_{0}$ diterima dan $H_{a}$ ditolak. Dengan demikian dapat disimpulkan bahwa tidak terdapat perbedaan antara kelas VIII B dan VIII C.

Kemampuan Akhir

Berdasarkan hasil analisis data diperoleh informasi ternyata varians untuk kelas eksperimen dan kelas kontrol yang diperoleh adalah lebih kecil dari taraf signifikan $5 \%$, dengan $F_{\text {hitung }}<\mathrm{F}_{\text {tabel }}$ atau 1,763<2,03 maka varians-varians adalah homogen. Sedangkan hasil uji normalitas, dapat diamati bahwa nilai $\chi_{\text {hitung }}^{2}$ kelas eksperimen sebesar 7,91 sedangkan untuk nilai $\chi^{2}{ }_{\text {hitung }}$ kelas kontrol sebesar 4,44. Harga $\chi_{\text {tabel }}{ }_{\text {dalam taraf }}$ signifikansi 5\% adalah 14,067 untuk kelas eksperimen dan 18,307 untuk kelas kontrol. Karena telah memenuhi kedua syarat tersebut, barulah analisis data dengan tes " $t$ " dapat dilakukan. Nilai $t_{\text {hitung }}=2,72$ berarti bahwa $t_{\text {hitung }}$ lebih besar $\mathrm{t}_{\text {tabel }}$ baik pada taraf signifikan 5\% maupun taraf signifikan $1 \%$ dengan degrees of freedom $(\mathrm{df})=\mathrm{N}_{\mathrm{x}}$ $+\mathrm{N}_{\mathrm{y}}-2=23+23-2=44$. Dalam tabel tidak terdapat $\mathrm{df}=44$, maka dari itu digunakan df yang mendekati 44 yaitu $\mathrm{df}=45$. Dengan df 45 diperoleh dari tabel pada taraf signifikan 5\% dan 1\% sebesar 2,02 dan 2,69. Ini berarti $t_{\text {hitung }}>t_{\text {tabel}}$, maka diputuskan bahwa $\mathrm{H}_{0}$ ditolak dan $\mathrm{H}_{\mathrm{a}}$ diterima yang berarti pemecahan masalah 
48 Instructional Development Journal (IDJ), Vol. 1, No. 1, Juni 2018, Hal. 45-50

matematika variabel X lebih tinggi dari variabel Y. Dengan demikian dapat disimpulkan bahwa terdapat perbedaan kemampuan pemecahan masalah antara siswa yang belajar menggunakan model kooperatif tipe CIRC dengan siswa yang memperoleh pembelajaran konvensional. Perbedaan mean kedua variabel juga menunjukan kelas eksperimen dengan pembelajaran kooperatif tipe CIRC lebih baik dari pada kelas konvensional.

\section{Peningkatan Hasil Belajar}

Berdasarkan nilai N-Gain, dapat diamati bahwa nilai $L_{\text {hitung }}$ kelas eksperimen sebesar 0,1689 sedangkan untuk nilai $L_{\text {hitung }}$ kelas kontrol sebesar 0,1604. Harga $L_{\text {tabel }}$ dalam taraf signifikansi 5\% untuk kelas eksperimen adalah 0,1730 dan kelas kontrol 0.1730. Dengan demikian $L_{\text {hitung }}<L_{\text {tabel }}$ maka dapat dikatakan bahwa data berasal dari populasi yang berdistribusi normal. Selanjutnya skor N-Gain diolah dengan menggunakan uji F. Hasil pengujian homogenitas bagi skor N-Gain untuk kelas eksperimen dan kelas kontrol. Maka varians untuk kelas eksperimen dan kelas kontrol yang diperoleh adalah lebih kecil dari taraf signifikan 5\%, dengan $\mathrm{F}_{\text {hitung }}<\mathrm{F}_{\text {tabel }}$ atau 1,907 <2,00 maka varians-varians adalah homogen. Karena telah memenuhi kedua syarat tersebut, kemudian dilanjutkan analisis data dengan tes " $\mathrm{t}$ " dapat menggunakan uji statistik Compare Mare Independent Samples Test. Nilai thitung $=4,07$ berarti bahwa thitung lebih besar $t_{\text {tabel }}$ pada taraf signifikan $5 \%$ maupun taraf signifikan $1 \%$ dengan $\mathrm{df}=\mathrm{N}_{\mathrm{x}}+\mathrm{N}_{\mathrm{y}}-2=23+23-2=44$. Dalam tabel tidak terdapat $\mathrm{df}=44$, maka dari itu digunakan $\mathrm{df}$ yang mendekati 44 yaitu $\mathrm{df}=45$. Dengan $\mathrm{df}$ diperoleh dari $\mathrm{t}_{\text {tabel }}$ pada taraf sidnifikan $5 \%$ dan $1 \%$ sebesar 2,02 dan 2,69. Ini berarti thitung $>t_{\text {tabel, }}$, maka diputuskan bahwa $\mathrm{H}_{0}$ ditolak dan $\mathrm{H}_{\mathrm{a}}$ diterima. Dengan demikian dapat disimpulkan bahwa terdapat peningkatan hasil belajar siswa yang menggunakan model kooperatif tipe CIRC.

\section{Aktifitas Guru}

Pertemuan pertama sampai dengan pertemuan keempat, bagi peneliti tidak ada kendala yang berarti. Pembelajaran dengan menggunakan model pembelajaran kooperatif tipe CIRC dapat terlaksanakan. Tiap pertemuan diawali dengan memberitahukan materi pembelajaran yang akan dipelajari, menjelaskan tujuan pelajaran serta memberitahukan bahwa model pembelajaran yang akan dilaksanakan adalah model pembelajaran kooperatif tipe CIRC, dan memotivasi siswa untuk belajar. Setelah itu peneliti membagi siswa berdasarkan kelompok heterogen, tiap kelompok beranggotakan empat orang. Pada tiap kelompok terdapat siswa yang tingkat kemampuannya tinggi, sedang dan rendah. Kemudian guru mengajukan masalah kehidupan sehari-hari yang relevan dengan materi, dan meminta siswa menanggapi masalah yang diajukann oleh peneliti. Kemudian peneliti membagikan LKS kepada siswa. Peneliti meminta siswa mendiskusikan permasalahan yang ada dalam LKS. Selama diskusi peneliti mengarahkan siswa. Setelah masing-masing kelompok selesai mendiskusikan permasalahan dalam LKS, peneliti menunjuk perwakilan masing-masing kelompok untuk mempresentasikan hasil diskusi kelompoknya. Diakhir pelajaran guru dan siswa bersama-sama menyimpulkan materi yang sudah dipelajari kemudian guru memberikan soal kuis dan PR dan menutup pelajaran.

\section{Aktifitas Siswa}

Pada pertemuan pertama ini, sebahagian besar siswa masih bingung dengan perubahan sistem pembelajaran yang terjadi di dalam kelas yang tidak seperi biasanya.Terdapat juga siswa yang tidak turut serta dalam diskusi kelompok.Masih banyak siswa yang bermain-main saat belajar, kemudian banyak siswa yang menyerah ketika mereka tidak berhasil mendapatkan jawaban dari masalah yang dihadapi. Dalam proses pelaksanaan pembelajaran pertemuan kedua ini, masih banyak siswa yang belum terlibat secara aktif dalam mengikuti sistem pembelajaran yang baru ini. Kerja kelompok antar siswa masih belum maksimal terlaksana karena masih ditemui siswa yang hanya menerima saja hasil dari diskusi kelompoknya.Hal ini disebabkan siswa belum terbiasa dengan keterampilan memecahkan masalah sehingga siswa masih enggan untuk turut aktif secara penuh, tetapi intensitas siswa yang tidak serius sudah mulai berkurang dari pertemuan pertama. Pada pertemuan ketiga ini, kegiatan pembelajaran yang dilakukan siswa terlihat lebih baik daripada pertemuan sebelumnya walaupun masih terdapat beberapa siswa yang belum terlibat secara aktif dalam mengikuti sistem pembelajaran yang telah ditetapkan.Akan tetapi, siswa yang memiliki kemampuan lemah masih terlihat kesulitan untuk mengikuti strategi kooperatif tipe CIRC, sehingga mereka hanya menunggu jawaban dari teman sebelahnya. 
Pada pertemuan keempat ini, keadaan udah mulai membaik, walaupun masih ada siswa yang berusaha bertanya kepada temannya.

Berdasarkan hasil penelitian yang diperoleh terlihat bahwa mean hasil postest siswa yang menggunakan Model Pembelajaran kooperatif tipe CIRC lebih tinggi dari pada mean hasil postest siswa yang belajar dengan model pembelajaran konvensional. Dimana mean kelas eksperimen adalah 83,30 dan kelas kontrol 73,96 dan dari analisa data postes dan N-Gain juga menunjukkan perbedaan dimana kelas eksperimen lebih unggul dibandingkankan kelas kontrol. Sebagaimana yang dikatakan Sugiyono (2010), jika kelompok treatment atau kelompok yang diberikan perlakuan lebih baik dari pada kelompok kontrol, maka perlakuan yang diberikan pada kelompok treatment berpengaruh positif. Dengan demikian hasil analisa ini mendukung rumusan masalah yang diajukan yaitu terdapat perbedaan dan peningkatan kemampuan pemecahan masalah matematika antara siswa yang belajar menggunakan Model pembelajaran Kooperatif tipe CIRC dengan siswa yang memperoleh pembelajaran konvensional. Dilihat dari ketuntasan klasikal antara kelas eksperimen dengan kelas kontol juga terlihat perbedaan dimana untuk kelas eksperimen ketuntasan klasikalnya mencapai 91\% sedangkan untuk kelas kontrol hanya $51 \%$ dan dapat dilihat pada lampiran $\mathrm{O}$, ini menjelaskan bahwa kemampuan pemecahan masalah matematika dengan menggunakan model pembelajaran kooperatif tipe CIRC lebih baik dari pembelajaran konvensional. Hal ini dimungkinkan karena pembelajaran telah berubah dari paradigma pembelajaran yang berpusat pada guru kepada pembelajaran yang menekankan pada keaktifan siswa dalam berpikir setelah proses membaca, selanjutnya berbicara dan membagi ide dengan temannya, kemudian menuliskan hasil diskusi. Dengan terjadinya interaksi antara siswa seperti yang dijabarkan diatas akan diperoleh banyak keuntungan, antara lain diskusi dan berbagi pengetahuan dan pendapat, refleksi atas hasil pemikiran masing-masing, dan akhirnya akan bermuara pada peningkatan pemahaman dan pemecahan masalah untuk masing-masing anggota kelompok.

\section{SIMPULAN DAN SARAN}

\section{Simpulan}

Berdasarkan hasil penelitian, dapat diambil kesimpulan sebagai berikut: 1) Terdapat perbedaan kemampuan pemecahan masalah dari penerapan pembelajaran kooperatif tipe CIRC siswa kelas VIII SMP Negeri 2 Bengkalis; dan 2) Terdapat perbedaan peningkatan hasil belajar siswa yang menggunakan model kooperatif tipe CIRC dengan pembelajaran konvensional yaitu dengan nilai N-Gain untuk kelas eksperimen 0,78 adalah kriteria tinggi dan kelas kontrol 0,68 adalah kriteria sedang.

\section{Saran}

Berdasarkan hasil penelitian ini, peneliti memberikan saran atas beberapa kendala yang dihadapi peneliti selama penelitian, adapun kendala-kendala dan saran, yaitu: 1) Kurangnya kerjasama siswa dalam belajar apabalagi belajar secara kelompok maka menyebabkan kurang maksimal penerapan CIRC, maka peneliti menyarankan untuk menerapkan CIRC sebaiknya membangun motivasi siswa untuk belajar agar lebih dapat bekerjasama dalam proses belajar mengajar agar mendapatkan hasil lebih maksimal; 2) Kurang matangnya dalam membuat skenario pembelajaran kooperatif tipe CIRC sehingga proses pembelajaran kurang maksimal, maka peneliti menyarankan supaya bagi yang ingin menggunakan pembelajaran kooperatif tipe CIRC untuk membuat skenario pembelajaran kooperatif tipe CIRC dengan lebih matang baik instrumen berupa RPP, LKS dll yang dibutuhkan dalam proses pembelajaran; dan 3) Bahasan matematika yang dikembangkan dalam penelitian ini hanya terdiri dari satu kompetensi dasar. Masih terbuka peluang bagi peneliti lain untuk bereksperimen pada standar kompetensi yang lain atau sekolah lain. 
50 Instructional Development Journal (IDJ), Vol. 1, No. 1, Juni 2018, Hal. 45-50

\section{DAFTAR RUJUKAN}

Mulyono Abdurrahman. 2003. Pendidikan Bagi Anak Berkesulitan Belajar, Cet.II. Jakarta: Rineka Cipta.

John A. Van De Wallec. 2006. Elementary and Middle Shool Mathematics ,diterjemahkan oleh Suyono dengan judul: Matematika Sekolah Dasar dan Menengah Pengembangan Pengajaran, Cet.VI. Jakarta: Erlangga.

Robert E Slavin. 2005. Cooperative Learning,diterjemahkan oleh Narulita Yusron dengan judul Cooperative Learning. Bandung: Nusa Media.

Muslich. 2008. KTSP Pembelajaran Berbasis Kompetensi dan Kontekstual. Jakarta: PT. Bumi Aksara.

Syaiful Bahri Djamarah dan Aswan Zain. 2006. Strategi Belajar Mengajar. Jakarta: Rineka Cipta.

Isjoni. 2009. Pembelajaran kooperatif Meningkatkan Kecerdasan Komunikasi Antar Peserta Didik. Yogyakarta: Pustaka Pelajar.

Punaji Setyosari. 2010. Metode Penelitian Pendidikan. Jakarta: Kencana.

Riduwan. 2010. Belajar Mudah Penelitian Untuk Guru, Karyawan, dan Peneliti Pemula. Bandung: Alfabeta.

Hartono. 2008. SPSS 16.0. Analisis Data Statistika dan Penelitian. Yogyakarta: Pustaka Pelajar.

Sudjana. 2002. Metode Statistika. Bandung: Tarsito.

Sugiyono. 2010. Metode Penelitian Pendidikan Kuantitatif Kualitatif dan R \& D. Bandung: Alfabeta.

Andi Supangat. 2010. Statistika dalam Kajian Deskriptif, Inferensi, dan Nonparametrik. Jakarta: Kencana.

Mimi Hariani. 2010. Pembelajaran Matematika Dengan Metode Penemuan Terbimbing Untuk Meningkatkan Pemahaman Konsep Dan Kemampuan Penalaran Matematik Siswa Sekolah Dasar. Bandung: Program Studi Magister Pendidikan Dasar Sekolah Pasca Sarjana Universitas Pendidikan Indonesia. 